$\operatorname{CONF}-9409160--1$

\title{
500 MW DEMONSTRATION OF ADVANCED WALL-FIRED COMBUSTION TECHINIQUES FOR THE REDUCTION OF NITROGEN OXIDE EMISSIONS FROM COAL-FIRED BOILERS
}

\author{
John N. Sorge \\ Steve M. Wilson \\ Southern Company Services, Inc. \\ P. O. Box 2625 \\ Birmingham, Alabama 35202
}

\begin{abstract}
This paper discusses the technical progress of a U. S. Department of Energy Innovative Clean Coal Technology project demonstrating advanced wall-fired combustion techniques for the reduction of nitrogen oxide (NOx) emissions from coal-fired boilers. The primary objective of the demonstration is to determine the long-term NOx reduction performance of advanced overfire air (AOFA), low NOx burners (LNB), and advanced digital control/optimization methodologies applied in a stepwise fashion to a $500 \mathrm{MW}$ boiler. The focus of this paper is to (1) present final results from the AOFA, LNB, and LNB+AOFA test phases and (2) provide an overview of the advanced digital control/optimization methods scheduled for demonstration starting fall 1994. Results from various LNB and AOFA testing and optimization efforts over a four year period provided a progressive improvement in emissions performance as operating and technical familiarity increased.
\end{abstract}

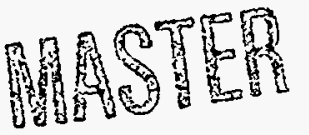




\section{TABLE OF ABBREVIATIONS}

\begin{tabular}{|c|c|}
\hline AOFA & Advanced Overfire Air \\
\hline ASME & American Society of Mechanical Engineers \\
\hline $\mathrm{C}$ & carbon \\
\hline $\mathrm{CF} / \mathrm{SF}$ & Controlled Flow/Split Flame \\
\hline $\mathrm{Cl}$ & chlorine \\
\hline $\mathrm{CO}$ & carbon monoxide \\
\hline DAS & data acquisition system \\
\hline DOE & United States Department of Energy \\
\hline ECEM & extractive continuous emissions monitor \\
\hline EPA & Environmental Protection Agency \\
\hline EPRI & Electric Power Research Institute \\
\hline F & Fahrenheit \\
\hline FC & fixed carbon \\
\hline FWEC & Foster Wheeler Energy Corporation \\
\hline $\mathrm{H}$ & hydrogen \\
\hline HHV & higher heating value \\
\hline ICCT & Innovative Clean Coal Technology \\
\hline $\mathrm{lb}(\mathrm{s})$ & pound(s) \\
\hline LNB & low NOx burner \\
\hline LOI & loss on ignition \\
\hline (M)Btu & (million) British thermal unit \\
\hline MW & megawatt \\
\hline $\mathrm{N}$ & nitrogen \\
\hline NOx & nitrogen oxides \\
\hline NSPS & New Source Performance Standards \\
\hline $\mathrm{O}, \mathrm{O}_{2}$ & oxygen \\
\hline psig & pounds per square inch gauge \\
\hline PTC & Performance Test Codes \\
\hline RSD & relative standard deviation \\
\hline $\mathbf{S}$ & sulfur \\
\hline SCS & Southern Company Services \\
\hline $\mathrm{SO}_{2}$ & sulfur dioxide \\
\hline UARG & Utility Air Regulatory Group \\
\hline VM & volatile matter \\
\hline
\end{tabular}

\section{DISCLAIMER}

This report was prepared as an account of work sponsored by an agency of the United States Government. Neither the United States Government nor any agency thereof, nor any of their employees, makes any warranty, express or implied, or assumes any legal liability or responsibility for the accuracy, completeness, or usefulness of any information, apparatus, product, or process disclosed, or represents that its use would not infringe privately owned rights. Reference herein to any specific commercial product, process, or service by trade name, trademark, manufacturer, or otherwise does not necessarily constitute or imply its endorsement, recommendation, or favoring by the United States Government or any agency thereof. The views and opinions of authors expressed herein do not necessarily state or reflect those of the United States Government or any agency thereof. 


\section{DISCLAIMER}

Portions of this document may be illegible in electronic image products. Images are produced from the best available original document. 


\section{INTRODUCTION}

This paper discusses the technical progress of one of the U. S. Department of Energy's Innovative Clean Coal Technology (ICCT) projects demonstrating advanced combustion techniques for the reduction of nitrogen oxide (NOx) emissions from wall-fired boilers. This demonstration is being conducted on Georgia Power Company's Plant Hammond Unit 4, a 500 MW, pre-NSPS (New Source Performance Standards), wall-fired boiler. Plant Hammond is located near Rome, Georgia, northwest of Atlanta.

This project is being managed by Southern Company Services, Inc. (SCS) on behalf of the project co-funders: The Southern Company, the U. S. Department of Energy (DOE), and the Electric Power Research Institute (EPRI). In addition to SCS, Southern includes the five electric operating companies: Alabama Power, Georgia Power, Gulf Power, Mississippi Power, and Savannah Electric and Power. SCS provides engineering and research services to the Southern electric system. The ICCT program is a jointly funded effort between DOE and industry to move the most promising advanced coal-based technologies to the commercial marketplace. The goal of ICCT projects is the demonstration of commercially feasible, advanced coal-based technologies that have already reached the "proof-of-concept" stage. The ICCT projects are jointly funded endeavors between the government and the private sector in which the industrial participant contributes at least 50 percent of the total project cost. The DOE is participating through the Office of Clean Coal Technology at the Pittsburgh Energy Technology Center (PETC).

The primary objective of the demonstration is to determine the long-term NOx reduction performance of advanced overfire air (AOFA), low NOx burners (LNB), and advanced digital control/optimization methodologies applied in a stepwise fashion to a $500 \mathrm{MW}$ boiler. Short-term tests of each technology are also being performed to provide engineering information about emissions and performance trends $[1,2,3]$.

Following a brief unit and technology review, this paper (1) presents the final results from the AOFA, LNB, and LNB+AOFA test phases and (2) provides an overview of the advanced digital control/optimization methods scheduled for demonstration starting fall 1994.

\section{UNIT AND TECHNOLOGY REVIEW}

Georgia Power Company's Plant Hammond Unit 4 is a Foster Wheeler Energy Corporation (FWEC) opposed wall-fired boiler, rated at $500 \mathrm{MW}$ gross, with design steam conditions of 2500 psig and $1000 / 1000^{\circ} \mathrm{F}$ superheat/reheat temperatures, respectively. The unit was placed into commercial operation on December 14, 1970. Prior to the LNB retrofit in 1991, six FWEC Planetary Roller and Table type mills provided pulverized eastern bituminous coal $(12,900 \mathrm{Btu} / \mathrm{lb}$, $33 \% \mathrm{VM}, 53 \% \mathrm{FC}, 72 \% \mathrm{C}, 1.7 \% \mathrm{~S}, 1.4 \% \mathrm{~N}, 10 \%$ ash) to 24 pre-NSPS, Intervane burners. The burners are arranged in a matrix of 12 burners $(4 \mathrm{~W} \times 3 \mathrm{H})$ on opposing walls with each mill supplying coal to four burners per elevation.

During a spring 1991 unit outage, the Intervane burners were replaced with FWEC Controlled Flow/Split Flame (CF/SF) burners. In the CF/SF burner, secondary combustion air is divided between inner and outer flow cylinders (Figure 1). A sliding sleeve damper regulates the total 
secondary air flow entering the burner and is used to balance the burner air flow distribution. An adjustable outer register assembly divides the burner's secondary air into two concentric paths and also imparts some swirl to the air streams. The secondary air that traverses the inner path, flows across an adjustable inner register assembly that, by providing a variable pressure drop, apportions the flow between the inner and outer flow paths. The inner register also controls the degree of additional swirl imparted to the coal/air mixture in the near throat region. The outer air flow enters the furnace axially, providing the remaining air necessary to complete combustion. An axially movable inner sleeve tip provides a means for varying the primary air velocity while maintaining a constant primary flow. The split flame nozzle segregates the coal/air mixture into four concentrated streams, each of which forms an individual flame when entering the furnace. This segregation minimizes mixing between the coal and the primary air, assisting in the staged combustion process.

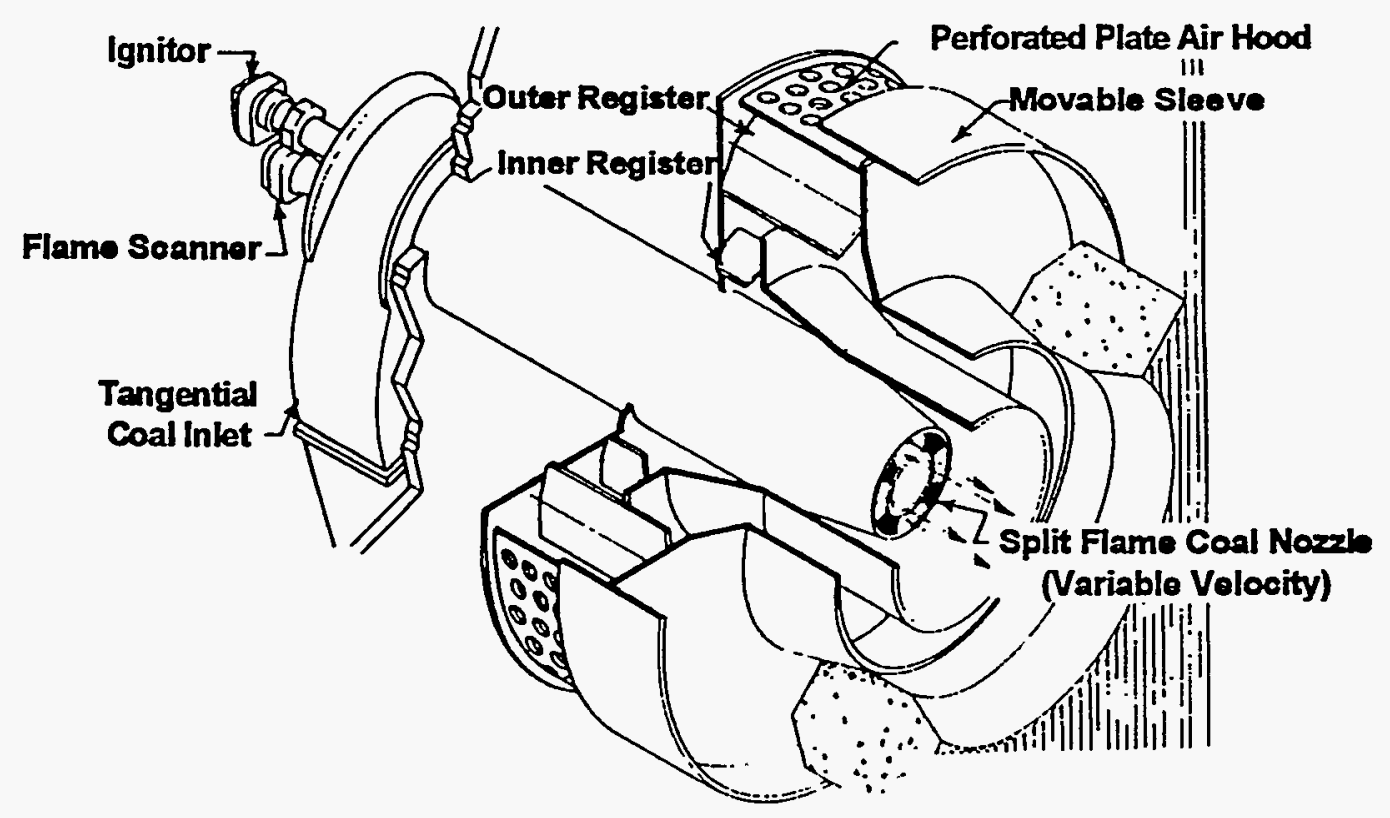

Figure 1. FWEC CF/SF Low NOx Burner

As part of this demonstration project, the unit was also retrofit with an Advanced Overfire Air (AOFA) system (Figure 2). The FWEC design diverts air from the secondary air ductwork and incorporates four flow control dampers at the corners of the overfire air windbox and four overfire air ports on both the front and rear furnace walls. Due to budgetary and physical constraints, FWEC designed an eight port AOFA system more suitable to the project and unit than the twelve port system originally proposed.

The Unit 4 boiler was designed for pressurized furnace operation but was converted to balanced draft operation in 1977. The unit is equipped with a coldside ESP and utilizes two regenerative secondary air preheaters and two regenerative primary air heaters. During the course of the ICCT demonstration, the unit was retrofitted with four Babcock \& Wilcox MPS 75 mills (two each during the spring 1991 and spring 1992 outages). 


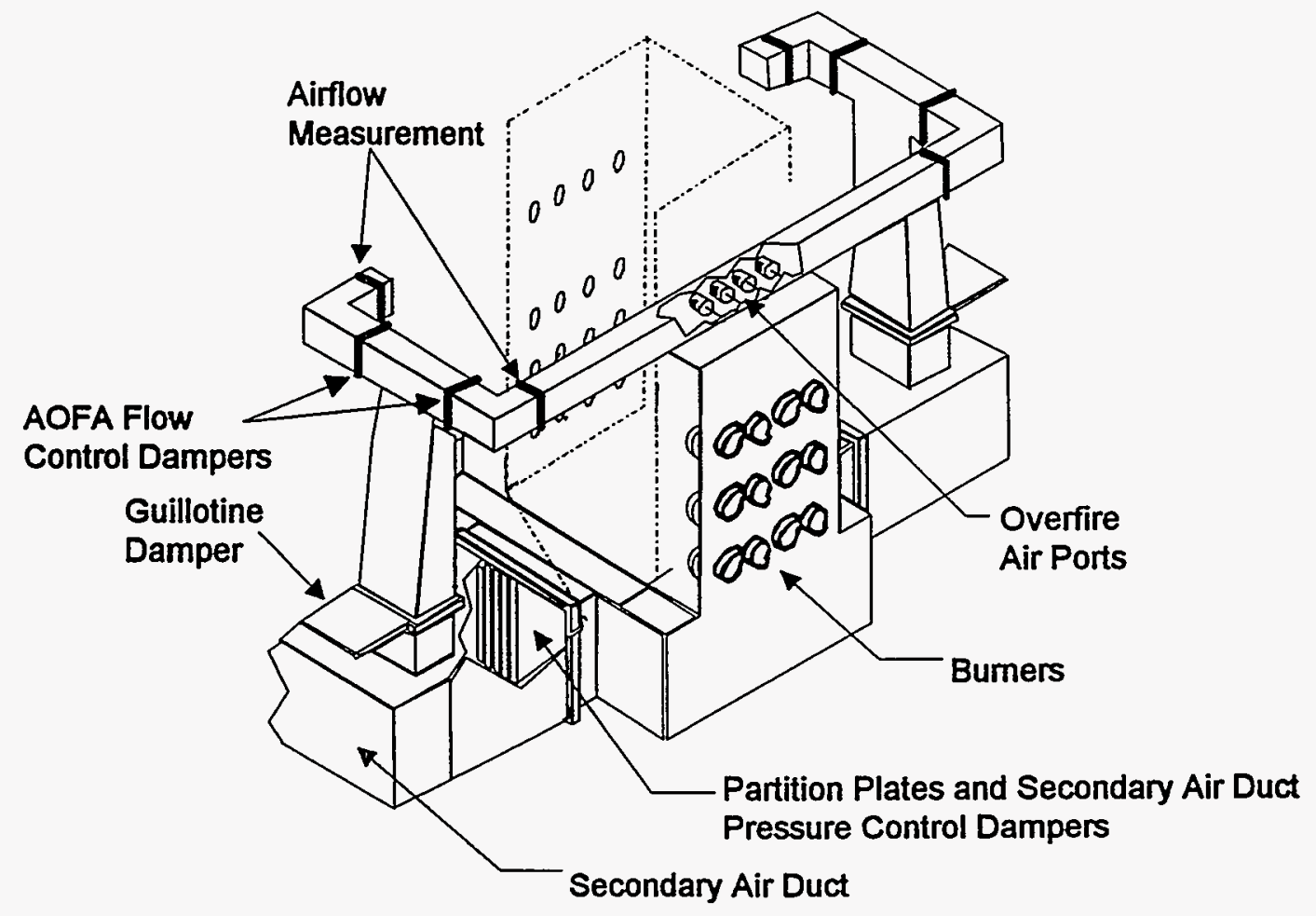

\section{REVIEW OF PRIOR TESTING}

Baseline, AOFA, LNB, and LNB+AOFA test phases have been completed (Table 1). Short-term and long-term baseline testing was conducted in an "as-found" condition from November 1989 through March 1990. Following retrofit of the AOFA system during a four-week outage in spring 1990, the AOFA configuration was tested from August 1990 through March 1991. The FWEC CF/SF low NOx burners were then installed during a seven week outage starting on March 8, 1991 and continuing to May 5, 1991. Following optimization of the LNBs and ancillary combustion equipment by FWEC personnel, LNB testing was commenced during July 1991. However, due to significant post-LNB increases in precipitator fly ash loading and gas flow rate and also, increases in fly ash LOI which adversely impacted stack particulate emissions, the unit was run below $300 \mathrm{MW}$ from September to November 1991 [4]. Following installation of an ammonia flue gas conditioning system, the unit was able to return to full load operation and complete the LNB test phase during January 1992.

\begin{tabular}{|c|l|c|c|}
\hline Phase & Description & Date & Status \\
\hline 0 & Pre-Award Negotiations & & \\
\hline 1 & Baseline Characterization & $8 / 89-4 / 90$ & Completed \\
\hline 2 & Advanced Overfire Air Retrofit (AOFA) \& Characterization & $4 / 90-3 / 91$ & Completed \\
\hline 3A & Low NOx Burner Retrofit (LNB) \& Characterization & $3 / 91-1 / 92$ & Completed \\
\hline 3B & LNB+AOFA Characterization & $1 / 92-8 / 93$ & Completed \\
\hline 4 & Digital Controls/Optimization Retrofit \& Characterization & $9 / 93-4 / 95$ & In Progress \\
\hline 5 & Final Reporting and Disposition & $5 / 95-12 / 95$ & Later \\
\hline
\end{tabular}

Table 1. Project Schedule 
Given the extended LNB test phase, insufficient time was available to complete the full requirements of the LNB+AOFA test phase prior to the spring 1992 outage; therefore it was decided to collect abbreviated data prior to this outage and comprehensive data following the outage. Following the outage, it was found that the AOFA had exacerbated the stack particulate emissions and the unit was again load limited, this time to $450 \mathrm{MW}$. While efforts were made to resume full load operation, special tests (i.e., NOx vs. LOI) were performed and long-term data collected [3]. On March 30, 1993, Hammond Unit 4 resumed full load operation and comprehensive testing in the LNB+AOFA configuration began. Testing in the LNB+AOFA configuration was completed during August 1993.

\section{LNB+AOFA CHARACTERIZATION}

Following completion of the LNB test phase during January 1992, testing in the low NOx burner and advanced overfire air configuration was to begin with completion scheduled for late March 1992. However, due to delays associated with increased stack particulate emissions following the LNB installation, testing in the LNB+AOFA configuration could not be completed prior to the spring 1992 outage during which two new mills were to be installed. To obtain operating data prior to this outage, abbreviated testing (designated 3B') in the LNB+AOFA configuration was performed during February and March 1992. Following the spring 1992 outage, the unit ran at reduced loads (less than $450 \mathrm{MW}$ ) until spring 1993 to maintain stack particulate compliance. During this period, long-term data were collected and the NOx vs. LOI tests were performed.

Following resumption of full load operation on March 26, 1993, FWEC personnel re-optimized the unit starting March 30, 1993 and continuing through May 6, 1993. Subsequent to the reoptimization, comprehensive testing using LNB plus AOFA began and was completed August 25, 1993. As shown in Figures 3 and 4, full load NOx emissions (from the performance tests) are approximately $0.43 \mathrm{lb} / \mathrm{MBtu}$ with corresponding fly ash loss-on-ignition (LOI) values of 8 percent. At low loads ( $300 \mathrm{MW}$ ), NOx emissions and LOI are approximately $0.32 \mathrm{lb} / \mathrm{MBtu}$ and 5.5 percent, respectively. Also shown in Figures 3 and 4 are the results from the February-March 1992 testing in the same configuration. NOx emissions for the more recent round of testing are considerably below the NOx levels found in these earlier tests (see discussion below).

A total of 63 days of valid long-term NOx emissions data were collected during the LNB+AOFA test phase (Figure 5). Based on this data set, the full load, long-term NOx emissions are approximately $0.40 \mathrm{lb} / \mathrm{MBtu}$, which is consistent with that found during the short-term performance testing (Figure 3). However, at $300 \mathrm{MW}$, long-term NOx emissions are $0.38 \mathrm{lb} / \mathrm{MBtu}, 0.06 \mathrm{lb} / \mathrm{MBtu}$ higher than the short-term emissions at the same load with approximately the same excess air and AOFA flow rate. The cause of this disparity is unknown. Despite this difference, the short-term data is within the $90^{\text {th }}$ percentile range of the long-term data. As with the short-term data, the long-term NOx emissions obtained in the LNB+AOFA configuration during the May - August 1993 test period were significantly reduced over that obtained previously in this configuration. 


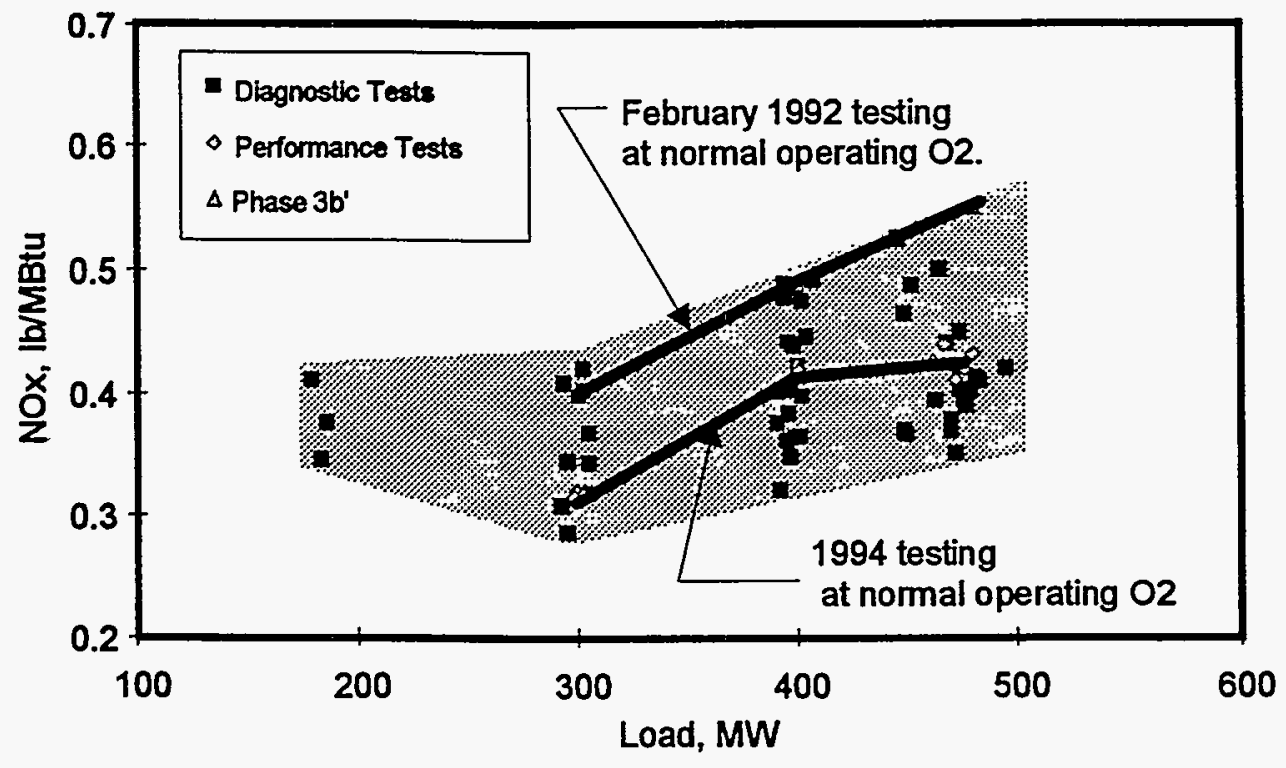

Figure 3. LNB+AOFA Short-Term NOx Emissions

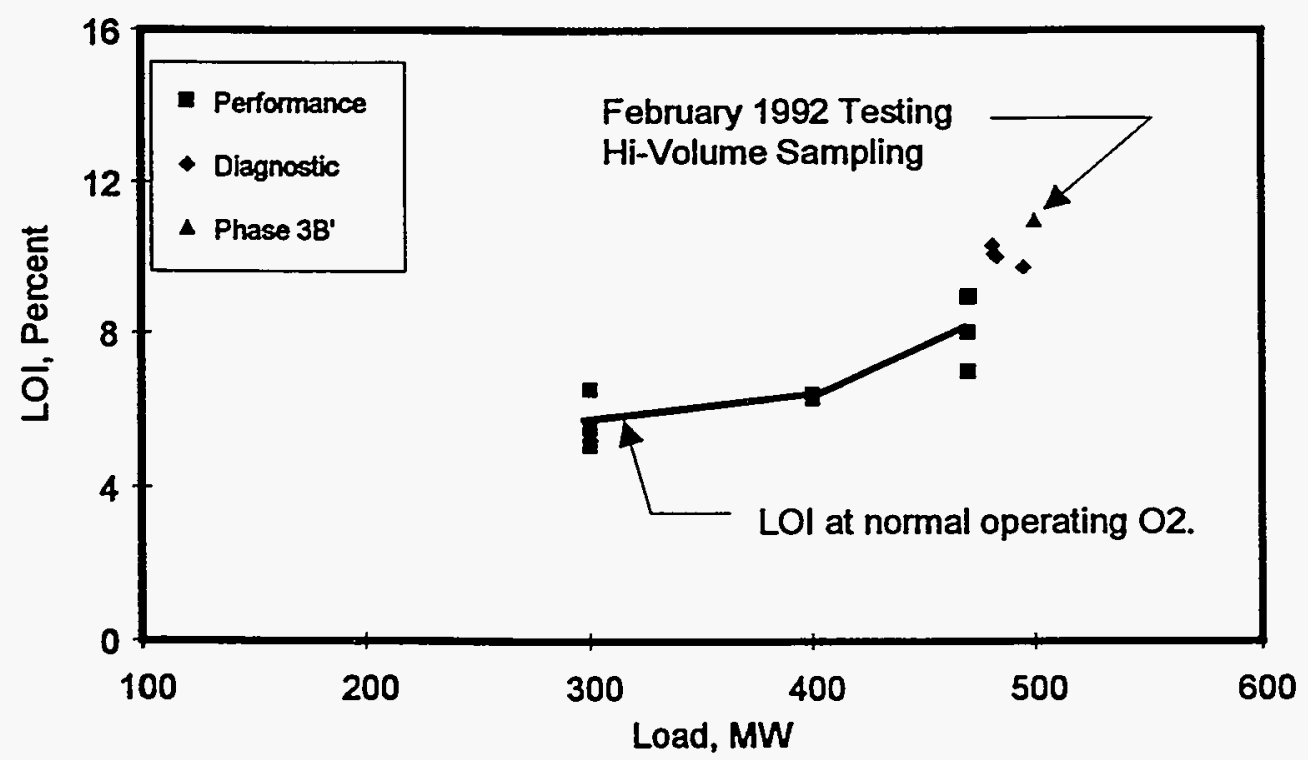

Figure 4. LNB+AOFA Short-Term Fly Ash Loss-on-Ignition 


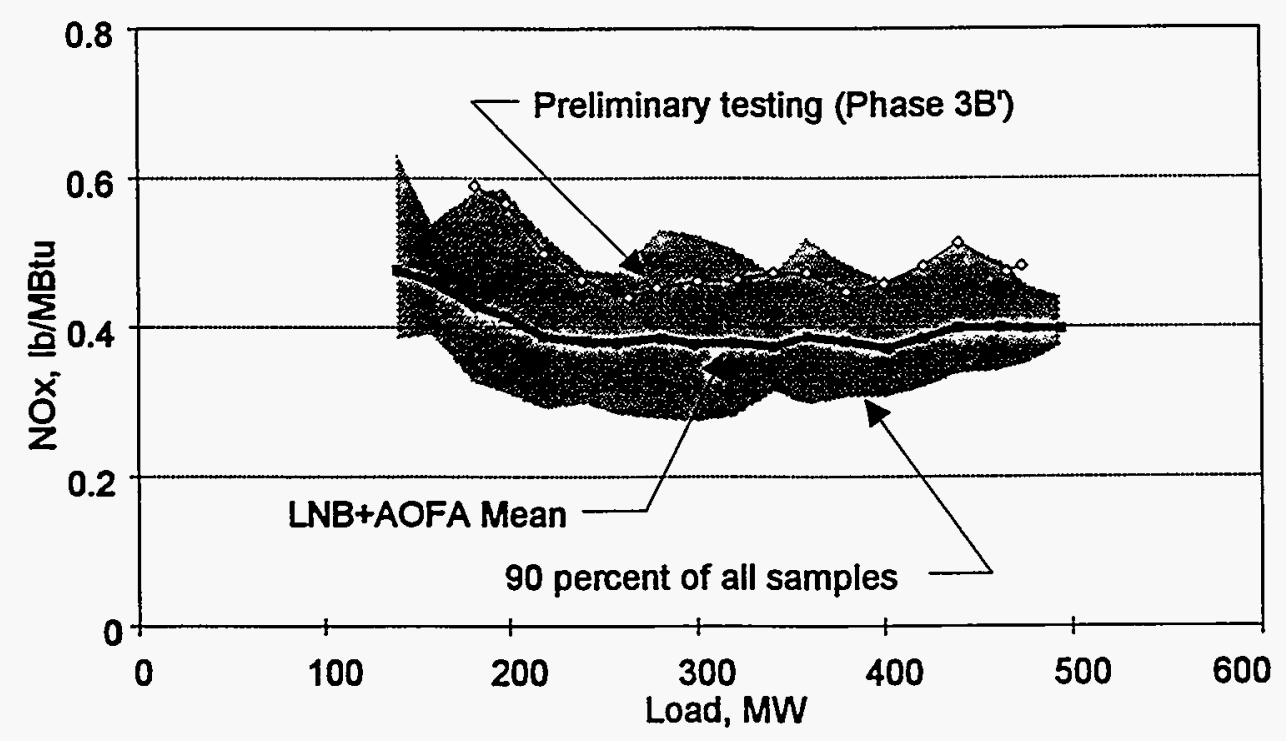

Figure 5. LNB+AOFA Long-Term NOx Emissions

\section{DATA COMPARISON}

As previously discussed, baseline, AOFA, LNB, and LNB+AOFA test phases have been completed. The following paragraphs discuss the final NOx and fly ash LOI results from these phases.

\section{NOx Reductions}

Figure 6 compares the baseline, AOFA, LNB, and LNB+AOFA long-term NOx emissions data for Hammond Unit 4. Baseline testing was performed in an "as-found" condition and the unit was not tuned for NOx emissions for this test phase. For the AOFA, LNB, and LNB+AOFA test phases, following optimization of the unit by FWEC personnel, the unit was operated according to FWEC instructions provided in the design manuals. As shown, the AOFA, LNBs, and LNB+AOFA provide a long-term, full load, NOx reduction of 24,48 , and 68 percent, respectively. The load-weighted average of NOx emissions reductions was 14, 48, and 63 percent, respectively, for AOFA, LNBs, and LNB+AOFA test phases.

The time-weighted average of NOx emissions for the baseline, AOFA, LNB, LNB+AOFA test phases are shown in Table 2. Since NOx emissions are generally dependent on unit load, the NOx values shown in this table are influenced by the load dispatch of the unit during the corresponding test frame. Also shown in this table are the $\mathbf{3 0}$ day and annual achievable emission limits (AEL) as determined during these test periods. The 30-day rolling average AEL is defined as the value that will be exceeded, on average, no more than one time per ten years. For the annual average, a compliance level of 95 percent was used in the calculation. 


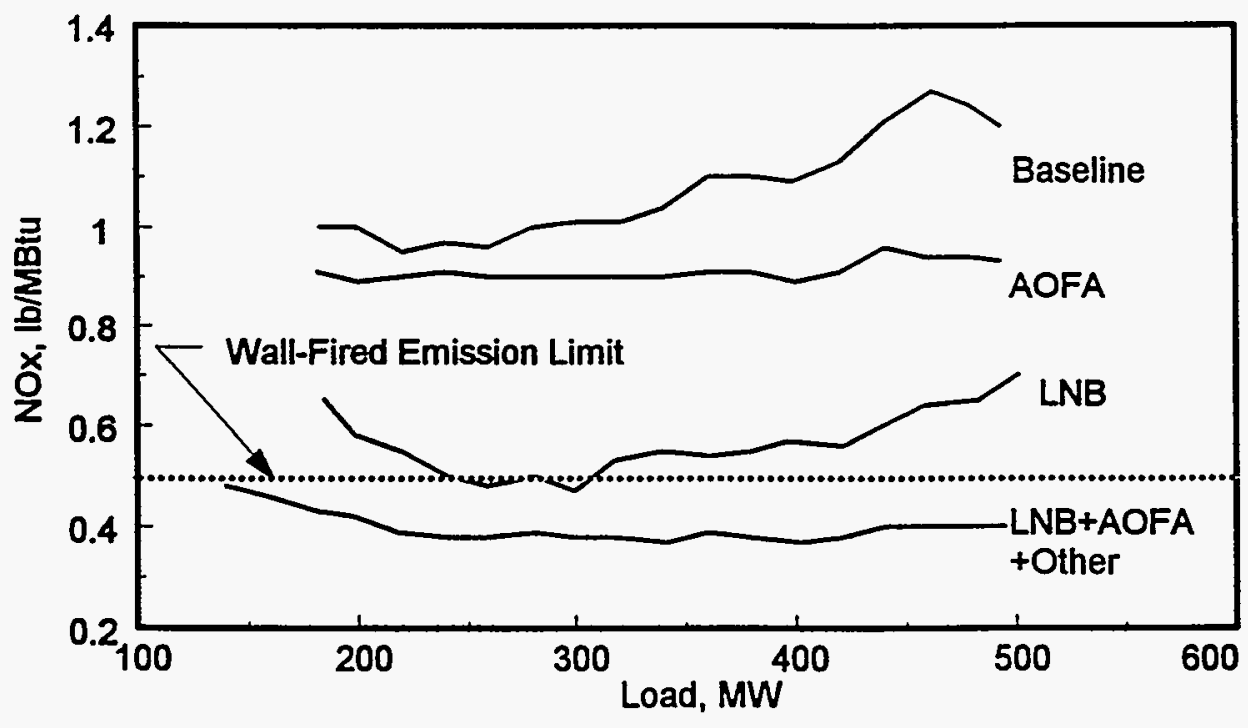

Figure 6. Long-Term NOx Emissions vs. Load Characteristic

\begin{tabular}{|l|c|c|c|c|c|c|c|c|}
\hline Unit Configuration $\rightarrow$ & \multicolumn{2}{|c|}{ Baseline } & \multicolumn{2}{c|}{ AOFA } & \multicolumn{2}{c|}{ LNB } & \multicolumn{2}{c|}{ LNB+AOFA } \\
\hline Parameter $\downarrow$ & Mean & RSD,\% & Mean & RSD, \% & Mean & RSD, \% & Mean & RSD, \% \\
\hline Number of Daily Avg. Values & 52 & - & 86 & - & 94 & - & 63 & - \\
\hline Load (MW) & 407 & 9.4 & 386 & 17.9 & 305 & 17.7 & 293 & 23.9 \\
\hline NOx Emissions (lb/MBtu) & 1.12 & 9.5 & 0.92 & 8.6 & 0.53 & 13.7 & 0.41 & 12.9 \\
\hline O2 Level (percent at stack) & 5.8 & 11.7 & 7.3 & 12.6 & 8.4 & 7.7 & 8.73 & 16.3 \\
\hline NOx 30 Day AEL (lb/MBtu) & 1.24 & - & 1.03 & - & 0.64 & - & 0.51 & - \\
\hline NOx Annual AEL (lb MBtu) & 1.13 & - & 0.93 & - & 0.55 & - & 0.42 & - \\
\hline
\end{tabular}

Table 2. Long-Term NOx Emissions

\section{Fly Ash Loss-On-Ignition}

The fly ash loss-on-ignition (LOI) values increased significantly for the AOFA and LNB test phases and similar increases have been experienced in the LNB+AOFA testing (Figure 7). These LOI increases were evident over the load range. The LOI measurements were made during each performance test using fly ash collected by EPA's Method 17 at the secondary air heater outlet [5]. The NOx emissions from the performance tests are also shown in the same figure. As shown in Table 3, mill performance was generally better in the AOFA, LNB, and LNB+AOFA test phases than during baseline. The improvement in coal fineness was likely responsible for the reduction in fly ash LOI levels during the May-August 1993 LNB+AOFA test phase. Although it is commonly recognized that fuel fineness can have a pronounced effect on fly ash LOI, results from Plant Smith, Plant Gaston, and other sources indicate the direct impact of fuel fineness on NOx emissions is small $[6,7,8]$. As previously reported, the post LNB retrofit increase in fly ash LOI along with increases in combustion air requirements and fly ash loading to the precipitator, has had an adverse impact on the unit's stack particulate emissions [4]. 

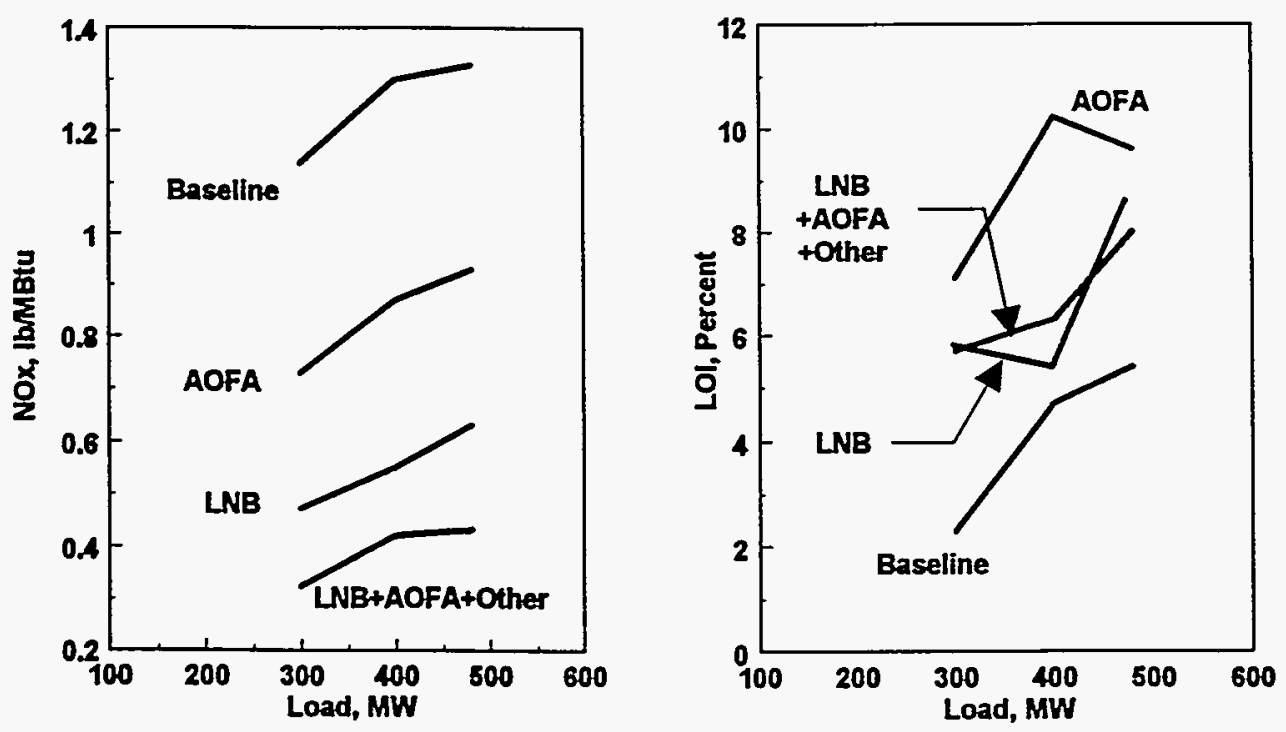

Figure 7. Performance Test Results

\begin{tabular}{|c|c|c|}
\hline \multirow{2}{*}{ Technology } & \multicolumn{2}{|c|}{ Coal Fineness } \\
\cline { 2 - 3 } & $\begin{array}{c}\text { Passing 200 Mesh } \\
\text { Percent }\end{array}$ & $\begin{array}{c}\text { Remaining 50 Mesh } \\
\text { Percent }\end{array}$ \\
\hline Baseline & 63 & 2.8 \\
AOFA & 67 & 2.6 \\
LNB & 67 & 1.4 \\
LNB+AOFA & 74 & 0.6 \\
\hline
\end{tabular}

Table 3. Mill Performance Summary

\section{LNB to LNB+AOFA NOx Reduction}

As shown above, NOx emissions were reduced between the LNB and LNB+AOFA test phases. Factors contributing to this reduction are discussed below.

\section{Performance of AOFA System}

Figure 8 shows NOx emissions as a function of AOFA flow rate for the LNB+AOFA test phase. Using this curve to extrapolate to zero overfire air flow, the NOx emission level of the furnace without AOFA can be estimated. Using this procedure for the LNB+AOFA test phase, the effectiveness of the AOFA system when added to the LNBs was approximately 16 percent indicating that much of the incremental NOx reduction achieved was not the result of the AOFA system, but was the result of other factors. Also, the 16 percent incremental

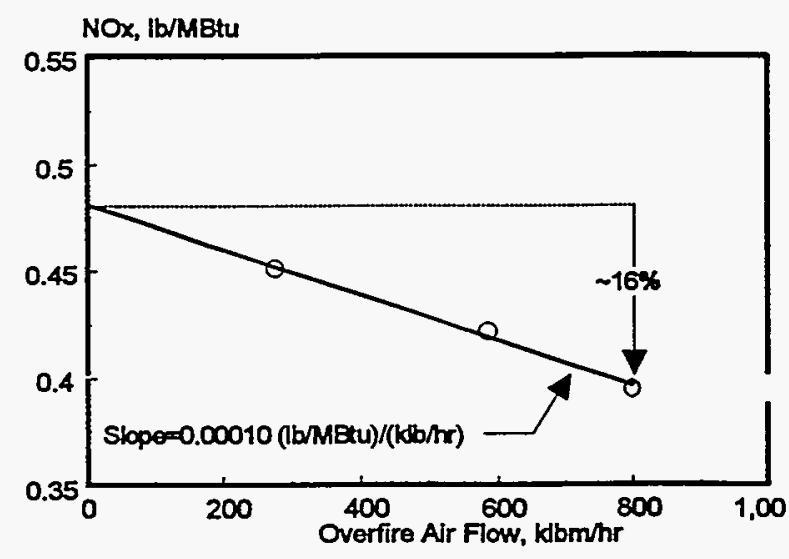

Figure 8. Effectiveness of AOFA System 
NOx reduction effectiveness of AOFA is more in concordance with prior experience with this technology at this site and elsewhere.

\section{Biasing of the Primary Coal and Air Flows}

The results of the special NOx vs. LOI testing are shown in Figure 9 [3]. As shown, other than excess oxygen, mill biasing had more impact on NOx emissions than any of the other parameters tested. As determined from these tests, the most favorable mill bias configuration was with the upper mills positively biased (more coal flow than average) and the lower mills negatively biased (less coal flow than average).

Figure 10 shows the mill loading for the LNB and LNB+AOFA test phases. During the LNB+AOFA test phase, mill biasing was in a NOx favorable configuration with the top mills having approximately 25 percent higher coal flow rates than the bottom mills. The mill bias was not as NOx favorable during the LNB test phase. Using the NOx vs. mill bias sensitivity, the NOx impact of this inadvertent bias can be estimated as being approximately $0.08 \mathrm{lb} / \mathrm{MBtu}$.

\section{Fuel Impacts}

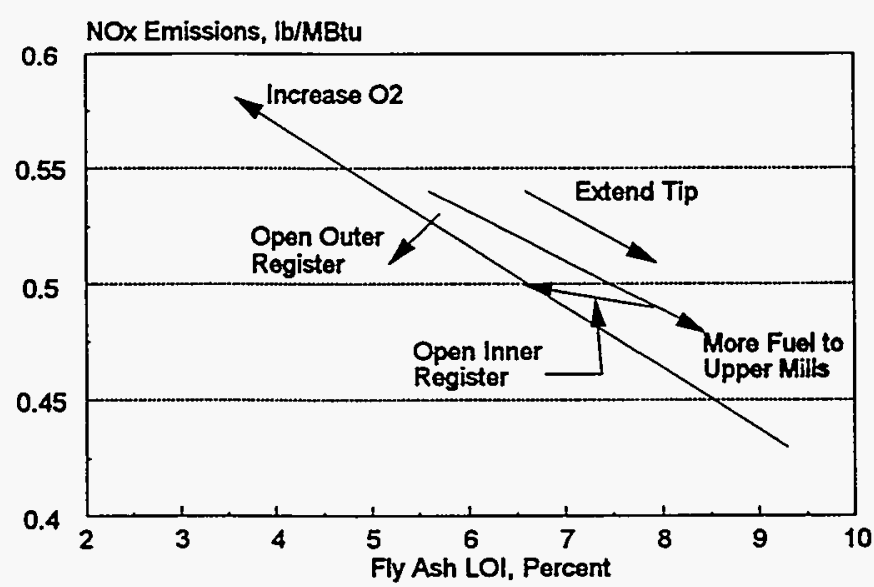

Figure 9. NOx vs. LOI Tests / All Sensitivities

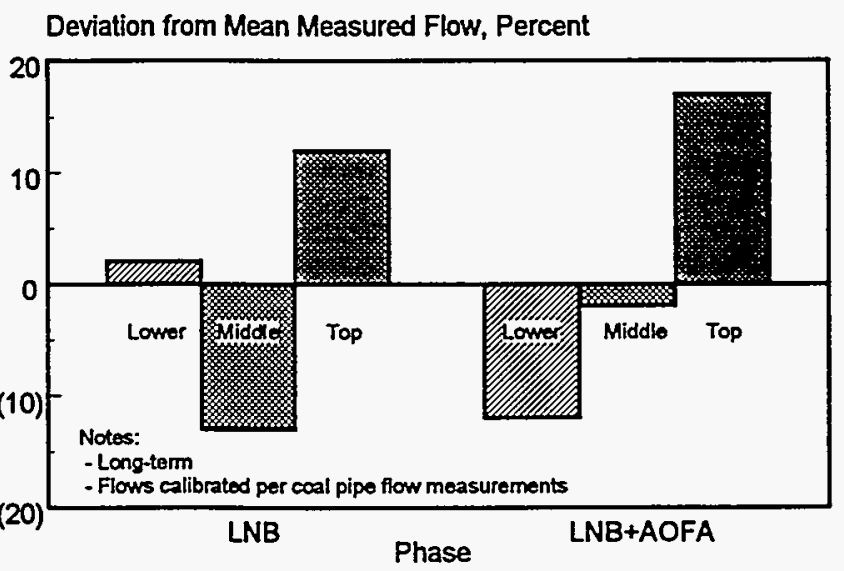

Figure 10. Mill Bias

A comparison of the fuels burned during the LNB and LNB+AOFA test phases is shown in Table 4. Largely as the result of changes in the coal nitrogen and the fixed carbon to volatiles ratio, the difference in fuel quality may have resulted in a $0.04 \mathrm{lb} / \mathrm{MBtu}$ reduction in NOx emissions between the LNB and LNB+AOFA test phases.

\section{Additional Combustion Tuning}

Subsequent to the completion of the LNB test phase and preceding the comprehensive LNB+AOFA testing, FWEC personnel were on site 75 days conducting combustion optimization. The overall impact of this optimization on NOx emissions is difficult to quantify and may have had a neutral (or even adverse) impact on NOx emissions. 


\begin{tabular}{|l|c|c|c|c|c|c|}
\hline & & \multicolumn{5}{|c|}{ Phase } \\
\cline { 3 - 7 } & Units & Baseline & AOFA & 3A & $\begin{array}{c}\text { 3B' } \\
\text { LNB+AOFA }\end{array}$ & $\begin{array}{c}\text { 3B } \\
\text { LNB+AOFA }\end{array}$ \\
\hline Moisture & $\%$ & 4.28 & 5.60 & 5.69 & 5.51 & 6.42 \\
Carbon & $\%$ & 72.40 & 73.17 & 72.53 & 72.90 & 70.78 \\
Hydrogen & $\%$ & 4.69 & 4.72 & 4.67 & 4.68 & 4.66 \\
Nitrogen & $\%$ & 1.43 & 1.42 & 1.39 & 1.30 & 1.39 \\
Sulfur & $\%$ & 1.72 & 1.64 & 1.53 & 1.74 & 1.67 \\
Ash & $\%$ & 9.80 & 8.90 & 9.44 & 9.52 & 9.51 \\
Oxygen & $\%$ & 5.65 & 4.55 & 4.74 & 4.36 & 5.57 \\
Total & $\%$ & 99.97 & 100.00 & 99.99 & 100.01 & 100.00 \\
HHV & Btu/lbm & 12921 & 13000 & 12869 & 12919 & 12494 \\
FC/Vol & & 1.57 & 1.57 & 1.61 & 1.65 & 1.50 \\
\hline
\end{tabular}

\section{Table 4 . Coal Comparison}

A summary of the factors discussed above are shown in Table 5. As shown, the NOx emissions obtained during the LNB+AOFA phase can be accounted for by the factors shown in this table.

\begin{tabular}{|c|l|c|c|l|}
\hline & & $\begin{array}{c}\text { Resultant } \\
\text { NOx } \\
\text { Phase }\end{array}$ & $\begin{array}{c}\text { NOx } \\
\text { Reduction* } \\
\text { Percent }\end{array}$ & Comments \\
\hline $3 A$ & ENB & $0.65 \mathrm{lb} / \mathrm{MBtu}$ & 47 & Full-Load / Long-Term / As Tested \\
& +AOFA & $0.54 \mathrm{lb} / \mathrm{MBtu}$ & 9 & $16 \%$ Effectiveness \\
& +Biasing & $0.46 \mathrm{lb} / \mathrm{MBtu}$ & 7 & $10 \%$ Upper Mill Bias \\
& +Fuel & $0.42 \mathrm{lb} / \mathrm{MBtu}$ & 3 & With 3B fuel \\
& +Tuning & $?$ & $?$ & Additional Tuning \\
& Total & $0.42 \mathrm{lb} / \mathrm{MBtu}$ & 66 & Estimated Using Above Factors \\
\hline $3 B$ & LNB+AOFA+Others & $0.40 \mathrm{lb} / \mathrm{MBtu}$ & 68 & Full-Load/Long-Term / As Tested \\
\hline
\end{tabular}

* Relative to baseline

\section{Table 5. NOx Accounting}

\section{ADVANCED CONTROLS AND OPTIMIZATION}

The objective of this scope addition to the project at Plant Hammond is to evaluate and demonstrate the effectiveness of advance digital control/optimization methodologies as applied to the NOx abatement technologies installed at this site (LNB and AOFA). This scope addition will provide documented effectiveness of these control/optimization methods on NOx emissions and boiler efficiency improvements and guidelines for retrofitting boiler combustion controls for NOx emission reduction. The major task for this project addition include: (1) design and installation of a distributed digital control system (DCS), (2) instrumentation upgrades, (3) advanced controls/optimization design and implementation, and (4) characterization of the unit both before and after activation of the advanced strategies. Major milestones are shown in Table 6. 


\begin{tabular}{|l|c|}
\hline \multicolumn{1}{|c|}{ Milestone } & Status \\
\hline Digital control system design, configuration, and installation & Completed \\
Digital control system startup & Completed \\
Instrumentation upgrades & In Progress \\
Advanced controls/optimization design & In Progress \\
Characterization of the unit prior to activation of advanced strategies & Scheduled 8/94 - 10/94 \\
Characterization of the unit following activation of advanced strategies & Scheduled 10/94 -2/95 \\
\hline
\end{tabular}

\section{Table 6. Advanced Controls / Optimization Major Activities}

The software and methodology to be demonstrated at Hammond is the Generic NOx Control Intelligent System (GNOCIS) whose development is being funded by a consortium consisting of the Electric Power Research Institute, PowerGen (a U.K. power producer), The Southern Company, U.K. Department of Trade and Industry, and U.S. Department of Energy [9]. The objective of the GNOCIS project is to develop an on-line enhancement to existing digital control systems that will result in reduced NOx emissions, while meeting other operational constraints on the unit (principally heat rate and other regulated emissions). The core of the system will be a model of the NOx generation characteristics of a boiler, that will reflect both short-term and longer-term shifts in boiler emission characteristics. The software will apply an optimizing procedure to identify the best set points for the plant. The recommended set points will be conveyed to the plant operators via the DCS or, at the plants discretion, the set points will be implemented automatically without operator intervention. The software will incorporate sensor validation techniques and be able to operate during plant transients (i.e. load ramping, fuel disturbances, and others). Figure 11 shows where GNOCIS fits with the rest of the digital control system.

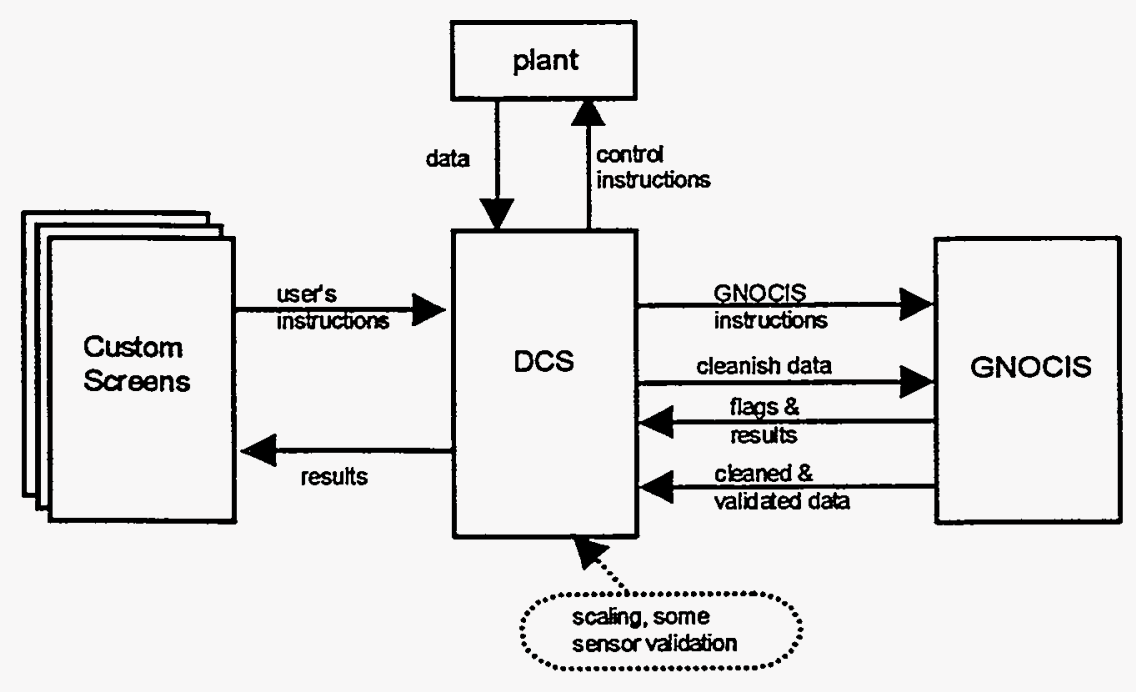

Figure 11. GNOCIS Functional Context

Following an initial feasibility study in which several promising methodologies were evaluated, a technique based on neural networks was selected to fulfill the "core" technology role in GNOCIS, 
i.e. to form the basis of the process and control models necessary to perform on-line optimization. Figure 12 shows a typical "actual vs. predicted" plot of NOx emissions using data collected from Hammond 4 during the LNB+AOFA test phase. The data represents approximately 5 weeks of normal unit operation. These predictions of NOx emissions are based on boiler operating parameters such as excess $\mathrm{O}_{2}$ and mill flows. In a parallel effort and as a safeguard if unforeseen and insurmountable problems arise with the neural network approach, design of alternate control/optimization strategies is also being pursued.

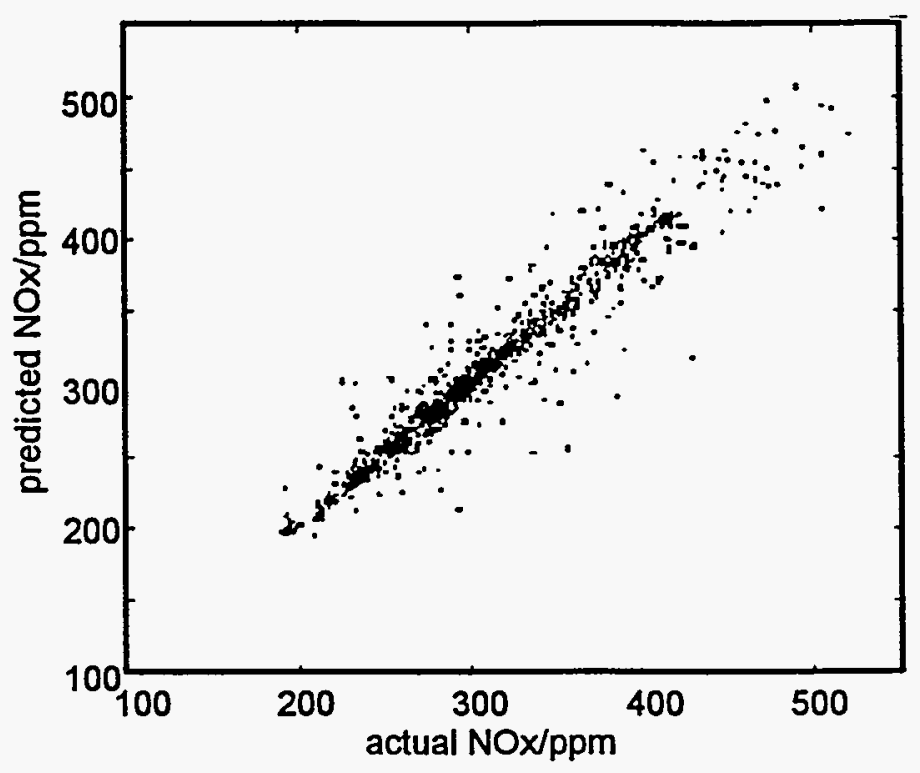

Figure 12. Actual vs. Predicted NOx Based on Hammond 4 Data

This GNOCIS software and methodology is currently under development and is scheduled to be implemented at PowerGen's Kingsnorth Unit 1 (a $500 \mathrm{MW}$ tangentially-fired unit with an ICL Level 3 Low NOx Concentric Firing System) and Alabama Power's Gaston Unit 4 (a 250 MW B\&W unit with B\&W XCL low NOx burners) prior to comprehensive testing at Hammond. Following "re-characterization" of Hammond 4 during August through October 1994, the advanced controls and optimization strategies will be activated and run open-loop. If the results from the open-loop testing warrant, the advanced controls/optimization package will be operated closed-loop with testing (short- and long-term) starting in October 1994 and continuing through February 1995.

\section{CONCLUSIONS}

In conclusion, the results to date at Plant Hammond indicate:

- NOx emissions have been reduced to about 50 percent of baseline values by using low NOx burners alone. These reductions were sustainable over the long-term test period and were consistent over the entire load range. Also, results indicate AOFA used in 
conjunction with the LNBs provide approximately 15 to 20 percent additional NOx reduction benefit over $\mathrm{LNB}$ alone.

- For all low NOx combustion configurations, the unit experienced significant performance impacts including increases in excess air and fly ash LOI.

- At Hammond 4, operational and burner adjustments which favorably impacted NOx emissions adversely affected fly ash unburned carbon levels.

- Advanced digital control and optimization strategies have the potential to favorably impact NOx emission levels.

\section{ACKNOWLEDGMENTS}

The authors wish to gratefully acknowledge the support and dedication of the following personnel: Mr. Ernie Padgett, Georgia Power Company, and Mr. Mike Nelson, Southern Company Services, for their coordination of the design and retrofit efforts, and Mr. Jose Perez, Instrumentation Specialist from Spectrum Systems, Inc. We also thank Mr. Jim Witt for his work coordinating the procurement and installation of the instrumentation. We would also like to recognize the following companies for their outstanding testing and data analysis efforts: Energy Technology Consultants, Inc., Flame Refractories, Inc., Southern Research Institute, W. S. Pitts Consulting, and Radian Corporation. Finally, the support from Mr. Art Baldwin, DOE Project Manager, and Dr. Rick Squires, EPRI Project Manager is greatly appreciated.

\section{REFERENCES}

1. $500 \mathrm{MW}$ Demonstration of Advanced Wall-Fired Combustion Techniques for the Reduction of Nitrogen Oxide Emissions from Wall-Fired Boilers - Phase 1 Baseline Tests. Southern Company Services, Birmingham, AL: 1991.

2. $500 \mathrm{MW}$ Demonstration of Advanced Wall-Fired Combustion Techniques for the Reduction of Nitrogen Oxide Emissions from Wall-Fired Boilers - Phase 2 Overfire Air Tests. Southern Company Services, Birmingham, AL: 1992.

3. $500 \mathrm{MW}$ Demonstration of Advanced Wall-Fired Combustion Techniques for the Reduction of Nitrogen Oxide Emissions from Wall-Fired Boilers - Phase 3A Low NOx Burner Tests. Southern Company Services, Birmingham, AL: 1994.

4. $500 \mathrm{MW}$ Demonstration of Advanced Wall-Fired Combustion Techniques for the Reduction of Nitrogen Oxide (NOx) Emissions from Coal Fired Boilers - Technical Progress Report - Third Quarter 1991. Southern Company Services Inc., Birmingham, AL: 1992.

5. U.S. Environmental Protection Agency. Determination of Particulate Emissions from Stationary Sources (In-Stack Filtration Methods), Federal Register 43(37):7884. Washington, D. C.: Government Printing Office, February 23, 1978. 
6. Hardman, R. R., Smith, L. L., Tavoulareas, S., "Results from the ICCT T-Fired Demonstration Project Including the Effect of Coal Fineness on NOx Emissions and Unburned Carbon Levels," EPA/EPRI 1993 Joint Symposium on Stationary Combustion NOx Control, May 24-27, 1993, Miami, Florida.

7. Sorge, J. N., Hardman, R. R., "The Effects of Low NOx Combustion on Unburned Carbon Levels in Wall-Fired Boilers," EPA/EPRI 1993 Joint Symposium on Stationary Combustion NOx Control, May 24-27, 1993, Miami, Florida.

8. Kinoshita, M., Kawamura, T., Kaneko, S., and Sakai, M., "New Approach to NOx Control Optimization and Unburnt Carbon Losses," EPA/EPRI 1989 Joint Symposium on Stationary Combustion NOx Control, March 6-9, 1989, San Francisco, California.

9. Holmes, R., Squires, R., Sorge, J., Chakraborty, R., Mcllvried, T., "Progress Report on the Development of a Generic NOx Control Intelligent System (GNOCIS)," EPRI 1994 Workshop on NOx Controls for Utility Boilers, May 11-13, 1994, Scottsdale, Arizona. 